\begin{tabular}{c|cc|}
\hline $\begin{array}{c}\text { ADESEARCH } \\
\text { ARTICLE }\end{array}$ & $\begin{array}{c}\text { ADANCE RESEARCH JOURNAL OF SOCIAL SCIENCE } \\
\text { volume } 7 \mid \text { Issue 2 | December, 2016 | 219-224 }\end{array}$ \\
\hline DOI: 10.15740/HAS/ARJSS/7.2/219-224 & Visit us : www.researchjournal.co.in \\
\hline
\end{tabular}

\title{
Quality of pre-school and its impact on cognitive development of children
}

Upasna Shishodia and Archana Kumari* International College for Girls, The IIS University, JAIPUR (RAJASTHAN) INDIA

(Email : archana.kumari@iisuniv.ac.in; 19archana.kumari@gmail.com)

\section{ARTICLE INFO :}

Received

Accepted : 10.11 .2016

\section{KEY WORDS :}

Cognitive development, Pre-school, Aanganwadi, Non-government organization

\section{HOW TO CITE THIS ARTICLE :}

Shishodia, Upasna and Kumari, Archana (2016). Quality of pre-school and its impact on cognitive development of children. Adv. Res. J. Soc. Sci., 7 (2) : 219-

224, DOI: 10.15740/HAS/ARJSS/7.2/ 219-224.

*Author for correspondence

\begin{abstract}
The significance of early childhood years has been well established through research evidences. According to Piaget, during early childhood, children learn through accommodating and assimilating new information they come across. The more the child is exposed to stimulating environment, the more he/she will learn. In India, the early childhood service is provided through government run Aanganwadis', Private pre-schools and pre-schools run by NGOs. The present study was undertaken to find out the quality of pre-schools and its impact on cognitive development of children. The data was collected from four pre-schools. From those four pre-schools, 80 children in the age group of 3-5 years were included in the sample. The findings of the study show a positive correlation between quality of pre-school and cognitive development of children. The children of private pre-school were found to lead ahead in cognitive development than children of pre-schools run by NGOs.
\end{abstract}

